The

Al] $]$ A

DOI : 10.15740/HAS/TAJAS/9.2/169-173

Visit us | www.researchjournal.co.in

- e ISSN-0976-8963

RESEARCH ARTICLE........

\title{
Histopathological alteration in gill of channa gachua exposed to an organophosphate
}

MUKESH KUMAR RAI AND A.P. MISHRA

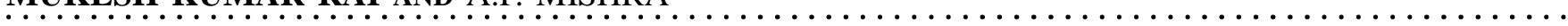

ABSTRACT...... Channa gachua (family channidae) is an air breathing fish which live in oxygen depleted muddy water. The gill of fish is main site of gas exchange, ion regulation and nitrogen waste excretion .When fish exposed to sub-lethal concentration of Profenofos, an organophosphate pesticide, this pesticide enters into fish mainly through gills. The histopathological changes in the gills, due to exposure

Author for Corresponding -

MUKESH KUMAR RAI

P.G. Department of Zoology,

B.R.Ambedkar Bihar University, MUZAFFARPUR (BIHAR) INDIA

Email: raimk1985@gmail.com

See end of the article for

Coopted authors' of Profenofos for 10 days, 15 days and 20 days include: curling and fusion in secondary lamellae, Hyperplasia, reduction in the respiratory surface area of filaments, fusion at the tip of the lamellae, sublamellar and sub epithelial space occur.

KEY WORDS...... Profenofos, Histopathology, Gill, Channa gachua

HOW TO CITE THIS ARTICLE - Rai, Mukesh Kumar and Mishra, A.P. (2014). Histopathological alteration in gill of Channa gachua exposed to an organophosphate. Asian J. Animal Sci., 9(2) : 169-173.

ARTICLE CHRONICLE - Received : 30.09.2014; Revised : 06.11.2014; Accepted : 21.11.2014 